\title{
Kepastian Hukum Eksekusi Dan Pembatalan Putusan Arbitrase Syariah Dalam Perspektif Politik Hukum
}

\author{
Ainun Najib \\ Fakultas Syariah dan Ekonomi Islam Universitas Ibrahimy Situbondo \\ Jln. KHR. Syamsul Arifin 20 Sumberejo Banyuputih Situbondo \\ adjie245@gmail.com
}

Received: 16 Juli 2019; Accepted: 24 Oktober 2019; Published: 17 Februari 2020

DOI: 10.20885/iustum.vol26.iss3.art7

\begin{abstract}
This study examines two main problems which are, firstly, to describe the juridical construction of granting the authority to execute and to annul an sharia arbitration award in the perspective of legal policy. Secondly, to provide the better alternatives for the development of national law in the future. This is a normative legal research, which studies the written legal sources to be analyzed by using both the statutory and conceptual approach. Through this study, it was concluded that first, legally, the granting of authority to carry out the execution and the annulment of the sharia arbitration award is still affected with dualism, which could lead to legal uncertainty. Second, it is necessary to synchronize the legislation regarding the authority to execute and to annul the sharia arbitration award to ensure the legal certainty, so that it will not conflict with one another. In the future, the execution and annulment of sharia arbitration should be placed in the Islamic Court, as they both apply the sharia principles.
\end{abstract}

Keywords: Legal certainty; execution; annulment; sharia arbitration; legal policy

Abstrak

Penelitian ini mengkaji dengan permasalahan utama, pertama, mendeskripsikan konstruksi yuridis pemberian kewenangan pelaksanaan eksekusi dan pembatalan putusan arbitrase syariah dalam perspektif politik hukum. Kedua, memberikan alternatif penyelesaian untuk pembangunan hukum nasional di masa yang akan datang. Penelitian ini merupakan penelitian hukum normatif, yang mengkaji sumber-sumber hukum tertulis yang dianalisis dengan menggunakan pendekatan perundangundangan dan pendekatan konseptual. Melalui kajian tersebut disimpulkan bahwa, pertama, secara yuridis pemberian kewenangan pelaksanaan eksekusi dan pembatalan putusan arbitrase syariah masih terdapat dualisme, yang dapat memberikan ketidakpastian hukum. Kedua, perlu dilakukan sinkronisasi peraturan perundang-undangan mengenai kewenangan pelaksanaan eksekusi dan pembatalan putusan arbitrase syariah guna menjamin kepastian hukum, agar tidak saling bertentangan antara satu dengan lainnya. Ke depan, eksekusi dan pembatalan arbitrase syariah seharusnya ditempatkan di Pengadilan Agama, karena sama-sama menggunakan prinsip-prinsip syariah.

Kata-kata Kunci: Kepastian hukum; eksekusi; pembatalan; putusan arbitrase syariah; politik hukum 


\section{Pendahuluan}

Hukum Islam secara luas dipatuhi dan dilaksanakan oleh kesadaran individu sejak awal kehidupan masyarakat di Nusantara. Namun, secara nasional, hukum yang berkaitan dengan perniagaan atau perikatan (muamalah) masih memiliki kecenderungan untuk menggunakan hukum perdata yang diadopsi dari hukum Belanda, dibanding dengan menggunakan hukum Islam. Hukum Belanda yang merupakan kelanjutan dari hukum Perancis atau Code Penal, menjadi hukum positif dalam sistem hukum Indonesia yang jamak digunakan oleh masyarakat Indonesia saat ini.

Bustanul Arifin ${ }^{1}$ berpandangan bahwa evaluasi kritis pada realitas hukum sipil dalam masyarakat Indonesia memiliki kecenderungan kepada hukum sipil Belanda, terutama dalam bidang perdagangan, perjanjian, maupun bentuk-bentuk perikatan lainnya. Padahal hukum sipil yang berasal dari Barat banyak memiliki perbedaan atau bertentangan dengan hukum Islam yang dianut oleh mayoritas masyarakat Indonesia. Pendapat ini didasarkan kepada realitas bahwa masyarakat Islam di Indonesia belum sepenuhnya menjalankan hukum Islam dalam semua aspek kehidupan secara sempurna, khususnya dalam aspek perniagaan dan perjanjian. Berbeda dengan hukum keluarga dan kewarisran Islam yang sangat mengakar kuat bahkan menyatu dalam tradisi masyarakat.

Seiring perkembangan kesadaran hukum sebagian masyarakat muslim Indonesia, pada akhir 1990-an kembali tumbuh minat penelaahan terhadap aspekaspek hukum Islam, khususnya di bidang muamalah yang meliputi bidang perniagaan, perjanjian atau perikatan dalam perspektif hukum Islam. Hal ini diikuti denga berdirinya Lembaga Keuangan Syariah (LKS) seperti perbankan syariah, asuransi syariah, pasar modal syariah, dengan berbagai instrumennya menjadi titik awal kajian-kajian nilai-nilai Islam dalam bidang muamalah. Sudah barang tentu untuk menjadikan hukum Islam sebagai hukum positif yang dinyatakan mengikat dan berlaku, haruslah dituangkan dalam bentuk hukum tertulis yang dilengkapi dengan

${ }^{1}$ Amrullah Ahmad, dkk., Dimensi Hukum Islam dalam Sistem Hukum Nasional; Mengenang 65 Tahun Prof. Dr. Bustanul Arifin, SH, Gema Insani Press, Jakarta,1996, hlm. 31. 
perangkat pendukung lainnya sebagai aktualisasi hukum Islam agar berlaku efektif dalam kehidupan masyarakat. ${ }^{2}$

Ekonomi syariah sebagai salah satu sistem ekonomi nasional memerlukan berbagai sarana pendukung agar dapat memberikan konstribusi yang maksimum bagi pengembangan ekonomi nasional. Sehingga pembentukan peraturan perndang-undangan yang memadai sebagai landasan yuridis pelaksanaan ekonomi syariah menjadi kebutuhan dan keniscayaan bagi berkembangnya lembaga tersebut, mengingat pertumbuhan dan volume usaha ekonomi baik bank dan non-bank yang berdasarkan prinsip-prinsip syariah tumbuh dan berkembang cukup pesat di Indonesia. Salah satu sarana pendukung vital adalah adanya pengaturan yang memadai dan sesuai dengan karakteristiknya mengenai penyelesaian sengketa ekonomi syariah yang mungkin terjadi diantara pihak pelaku bisnis atau ekonomi syariah. Namun selama ini masih terjadi tarik ulur kewenangan untuk menangani perkara ekonomi syariah.

Pasal 49 Undang-Undang Nomor 3 Tahun 2006 tentang Peradilan Agama memberikan kewenangan kepada peradilan agama untuk menyelesaikan persoalan sengketa ekonomi syariah, yaitu bagi mereka yang beragama Islam atau bagi orang yang menundukkan diri terhadap hukum Islam, mengingat Pengadilan Agama menjadikan hukum Islam sebagai sumber hukum materiil dalam menangani perkara yang menjadi kewenangannya.

"Pengadilan agama bertugas dan berwenang memeriksa, memutus, dan menyelesaikan perkara di tingkat pertama antara orang-orang yang beragama Islam di bidang: a) perkawinan; b) waris; c) wasiat; d) hibah; e) wakaf; f) zakat; g) infaq; h) shadaqah; dan i) ekonomi syari'ah."3

Pasal 55 Undang-Undang Nomor 21 Tahun 2008 tentang Perbankan Syariah, di sisi lain, dianggap telah mereduksi kewenangan absolut Pengadilan Agama dalam menangani sengketa ekonomi syariah dengan diberikannya opsi penyelesaian sengketa ekonomi syariah melalui Pengadilan Umum. Penjelasana Pasal 55 ayat (2) menegaskan bahwa: Yang dimaksud dengan "penyelesaian sengketa dilakukan sesuai dengan isi Akad" adalah upaya sebagai berikut: a)

${ }^{2}$ Fathurrahman Djamil, Hukum Ekonomi Islam; Sejarah, Teori dan Konsep, Sinar Grafika, Jakarta, 2013, hlm. 266.

3 Pasal 49 Undang-Undang Nomor 3 Tahun 2006 tentang Perubahan Undang-Undang Nomor 70 Tahun 1989 tentang Peradilan Agama. 
musyawarah; b) mediasi perbankan; c) melalui Badan Arbitrase Syariah Nasional (Basyarnas) atau lembaga arbitrase lain; dan/atau d) melalui pengadilan dalam lingkungan Peradilan Umum. Opsi pada point (d) tersebut kemudian dibatalkan atau dihapuskan oleh putusan Mahkamah Konstitusi Nomor PMK 93/PUUX/2012, karena dianggap bertentangan dengan kompetensi lembaga peradilan sebagaimana diatur dalam konstitusi yang ada.

Pelaksanaan eksekusi putusan arbitrase syariah juga pernah diatur melalui Surat Edaran Mahkamah Agung (SEMA) Nomor 8 Tahun 2008 tentang Eksekusi Putusan Badan Arbitrase Syari'ah, yang memberi kewenangan pelaksanaan eksekusi kepada Pengadilan Agama, setelah memeriksa perkara yang diajukan. Namun kemudian, SEMA Nomor 8 Tahun 2008 ini dibatalkan atau dicabut dan dinyatakan tidak berlaku lagi melalui SEMA Nomor 8 Tahun 2010, karena dianggap bertentangan dengan Undang-Undang Nomor 48 Tahun 2009 tentang Kekuasaan Kehakiman Pasal 59 ayat (3) dan penjelasannya. Dengan kata lain, undang-undang tersebut kembali menegaskan bahwa eksekusi putusan arbitrase syariah menjadi kewenangan Pengadilan Umum sebagaimana diatur di dalam Undang-Undang Nomor 30 Tahun 1999 tentang Arbitrase dan Alternatif Penyelesaian Sengketa.

Tarik ulur kewenangan tersebut tidak sampai di situ saja. Tahun 2016 Mahakamah Agung mengeluarkan peraturan tentang tata cara penyelesaian perkara ekonomi syariah. Dalam Pasal 13 ayat (2) PERMA Nomor 14 Tahun 2016 tentang Tata Cara Penyelesaian Perkara Ekonomi Syariah, dinyatakan bahwa pelaksanaan putusan arbitrase syariah dan pembatalannya, dilakukan oleh pengadilan dalam lingkungan peradilan agama. Dengan demikian, Pengadilan Agama berwenang secara penuh dalam melaksanakan eksekusi dan membatalkan putusan arbitrase syariah, dengan tetap mengacu kepada Undang-Undang Nomor 30 Tahun 1999, sebagai sumber hukum materiilnya. Secara internal, dualisme kewenangan antarlembaga peradilan di bawah naungan Mahkamah Agung tersebut bisa dikatakan sudah selesai. Namun secara yuridis, masih terdapat pertentangan norma antara Undang-Undang Nomor 48 Tahun 2009 Pasal 59 ayat (3), dengan PERMA Nomor 14 Tahun 2016 Pasal 13 ayat (2). 
Secara normatif, kompetensi absolut suatu lembaga pengadilan tidak cukup hanya dituangkan dalam Peraturan Mahkamah Agung, namun harus secara tegas dinyatakan dalam suatu undang-undang, agar tidak terjadi dualisme kewenangan dalam menyelesaikan suatu perkara yang sama. Karena kompetensi absolut suatu lembaga pengadilan tidak akan dimiliki oleh lembaga pengadilan yang lain. Terjadinya dualisme pemberian kewenangan dalam menangani penyelesaian sengketa ekonomi syariah, khususnya kewenangan dalam pelaksanaan eksekusi dan pembatalan terhadap putusan arbitrase syariah antara Pengadilan Negeri dan Pengadilan Agama ini tentu tidak terlepas dari konstelasi politik hukum yang masih ingin mereduksi kewenangan Pengadilan Agama, sebagai bias dari politik hukum yang pernah diterapkan oleh pemerintah kolonial Hindia Belanda, yang menjadikan Pengadilan Agama sebagai lembaga peradilan kelas dua.

Pasang surut perkembangan peradilan agama di Indonesia sebagai mana tercermin dalam Undang-Undang Peradilan Agama yang mengatur tentang hal itu dari waktu ke waktu berubah tergantung kepada dinamika dan konfigurasi politik hukum nasional. Namun demikian, peradilan agama di Indonesia dalam perkembangan terakhirnya telah mengalami perkembangan yang sangat signifikan dan memiliki kedudukan yang kuat dalam sistem peradilan di Indonesia, terlepas dari problem yang mengitarinya. ${ }^{4}$

Kepastian hukum dalam hal terjadinya dualisme kewenangan tersebut harus diupayakan melalui pembangunan peraturan hukum yang lebih komprehensif. Dengan pembentukan hukum yang baik, diharapkan persoalan penyelesaian sengketa ekonomi syariah menjadi semakin lebih baik pula serta memberikan rasa keadilan bagi masyarakat.

\section{Rumusan Masalah}

Berdasarkan uraian latar belakang di atas, maka studi ini akan memfokuskan pada rumusan masalah sebagai berikut, pertama, bagaimana konstruksi hukum eksekusi dan pembatalan putusan arbitrase syariah dalam perspektif politik hukum Indonesia? Kedua, bagaimana seharusnya pengaturan kewenangan

\footnotetext{
${ }^{4}$ Muhammad Faisol, "Pasang Surut Undang-Undang Peradilan Agama: Problem Penyelesaian Sengketa Ekonomi Syariah,” Jurnal al-Adalab Volume 16, Nomor 2, November 2012, hlm. 210-2011.
} 
pelaksanaan eksekusi dan pembatalan putusan arbitrase syariah dalam penyelesaian sengketa ekonomi syariah di Indonesia?

\section{Tujuan Penelitian}

Tujuan penelitian dimaksudkan untuk memberikan arah yang tepat dalam proses dan pelaksanaan penelitian yang dilaksanakan, agar penelitian ini berjalan sesuai dengan apa yang diharapkan. Penelitian ini memiliki tujuan pertama untuk mengkaji secara komprehensif tentang konstruksi hukum penyelesaian sengketa ekonomi syariah di Indonesia. Kedua untuk memformulasikan bagaimana seharusnya pengaturan kewenangan eksekusi dan pembatalan putusan arbitrase syariah dalam penyelesaian sengketa ekonomi syariah.

\section{Metode Penelitian}

Secara spesifik objek kajian penelitian ini adalah Undang-Undang Nomor 30 Tahun 1999 tentang Arbirase dan Alternatif Penyelesaian Sengketa, UndangUndang Nomor 3 Tahun 2006 jo. Undang-Undang Nomor 50 Tahun 2009 tentang Peradilan Agama, Undang-Undang Nomor 21 Tahun 2008 tentang Perbankan Syariah, Undang-Undang Nomor 48 Tahun 2009 tentang Kekuasaan Kehakiman, Putusan Mahkamah Konstitusi Nomor 93/PUU-X/2012, dan Peraturan Mahkamah Agung Nomor 14 Tahun 2016 tentang Tata Cara Penyelesaian Perkara Ekonomi Syariah.

Teknik pengumpulan data dalam penelitian ini menggunakan bahan kepustakaan dengan cara mengumpukan dan mempelajari bahan hukum primer, bahan hukum sekunder dan bahan hukum tersier. Studi pustaka dimaksud untuk mencari, mempelajari, menelaah dan menkaji berbagai dokumen dan bahan pustaka lainnya yang berkaitan dengan fokus penelitian, yaitu kompetensi pengadilan dalam melaksanakan dan membatalkan putusan arbitrase syariah dalam perspektif politik hukum di Indonesia. Data yang telah terkumpul dianalisis secara deskriptif-kualitatif. 


\section{Hasil Penelitian dan Pembahasan}

\section{Konstruksi Hukum Eksekusi dan Pembatalan Putusan Arbitrase Syariah dalam Perspektif Politik Hukum Indonesia}

Hukum bukanlah merupakan sesuatu yang sama sekali otonom, melainkan saling berkaitan dengan sektor-sektor kehidupan lain yang terdapat di dalam mayarakat. Untuk itu, hukum ditutut untuk senantiasa melakukan penyesuaianpenyesuaian terhadap tujuan yang hendak dicapai oleh masyarakatnya. Sehingga hukum memiliki dinamika yang akan mengarahkan hukum pada ius constituendum (hukum yang seharusnya berlaku). Salah satu instrumen untuk membawa hukum pada suatu tujuan yang hendak dicapai adalah dengan politik hukum.

Politik hukum secara etimologis merupakan terjemahan dari bahasa Belanda, rechtpolitiek, yang berarti politik hukum. Politik berarti beleid atau dalam bahasa Indonesia dapat maknai kebijakan. Sedangkan kebijakan menurut para ahli hukum merupakan serangkaian tindakan yang diusulkan seseorang, kelompok, atau pemerintah dalam suatu lingkungan tertentu dengan menunjukkan hambatan dan kesempatan terhadap pelaksanaan usulan kebijakan tersebut dalam rangka mencapai tujuan. ${ }^{5}$

Mahfud MD $^{6}$ mendefinisikan politik hukum sebagai legal policy atau garis (kebijakan) kebijakan resmi tentang hukum yang akan diberlakukan, baik dengan pembuatan hukum baru maupun dengan penggantian hukum lama, dalam rangka mencapai tujuan negara. Dengan demikian, politik hukum merupakan pilihan tentang hukum-hukum yang akan diberlakukan sekaligus pilihan tentang hukumhukum yang akan dicabut atau tidak diberlakukan, yang kesemuanya dimaksudkan untuk mencapai tujuan negara seperti yang tercantum di dalam Pembukaan UUD 1945.

Sunaryati Hartono ${ }^{7}$ mengungkapkan, bahwa pembangunan politik hukum nasional tidak terlepas dari cita-cita pembangunan masyarakat oleh bangsa Indonesia. Sehingga kemudian dapat dicari sistem hukum yang dapat membawa

${ }^{5}$ Abdul Manan, Politik Hukum: Studi Perbandingan dalam Pratik Ketatanegaraan Islam dan Sistem Hukum Barat, Prenada Media Group, Jakarta, 2016, hlm. 8.

${ }^{6}$ Moh. Mahfud MD, Politik. Hukum di Indonesia, Cetakan Keenam, Raja Grafindo Persada, Jakarta, 2014, hlm. 1.

${ }^{7}$ Sunaryati Hartono, Politik. Hukum Menuju Satu Sistem Hukum Nasional, Alumni, Bandung, 1991, hlm. 1. 
masyarakat menuju situasi yang dicita-citakan tersebut. Dengan demikian, barulah bisa diformulasikan politik hukum nasional yang dapat menciptakan sistem hukum nasional yang dikehendaki. Politik hukum berdasarkan pada realita sosial dan tradisional serta realita politik hukum internasional.

Abdul Hakim Garuda Nusantara ${ }^{8}$ mengungkapkan bahwasanya hukum seyogyanya harus senantiasa mengacu pada cita-cita masyarakat bangsa, yaitu tegaknya negara hukum yang demokratis dan berkeadilan sosial. Artinya, hukum harus dibangun untuk tujuan-tujuan mengakhiri suatu tatanan sosial yang tida adil dan yang menindas hak-ahak asasi manusia. Politik hukum Indonesia harus berorientasi pada cita-cita negara hukum yang didasarkan atas prinsip-prinsip demokrasi dan berkeadilan sosial dalam suatu masyarakat bangsa Indonesia yang bersatu sebagaimana yang tertuang dalam Pembukaan UUD 1945. Senada dengan pendapat Abdul Hakim Garuda Nusantara, Bernard L. Tanya9 menjelaskan mengenai posisi hukum dalam konteks politik hukum nasional, yaitu, pertama, hukum merupakan instrumen atau alat yang dipergunakan untuk mencapai tujuan. Kedua, hukum sebagai pembawa misi yang menjadi wadah untuk menampung segala aspirasi terhadap hal-hal yang ingin ditata atau dicapai. Ketiga, hukum sebagai piranti manajemen yang menata kepentingan-kepentingan secara adil serta menetapkannya secara proporsional.

Menurut Utrecht, ${ }^{10}$ politik hukum berusaha membuat kaidah-kaidah yang akan menentukan bagaimana seharusnya manusia bertindak, politik hukum berusaha menyelidiki perubahan-perubahan apa yang harus dilakukan terhadap hukum yang berlaku, agar sesuai dengan realitas sosial (sociale wekerlijkhed). Dapat dikatakan bahwa politik hukum meneruskan perkembangan hukum dengan berusaha melenyapkan sebanyak-banyaknya ketegangan antara positivitas dengan realitas sosial. Politik hukum membuat ius constituendum, dan berusaha agar hukum tersebut berlaku ius constitutum di kemudan hari. Meskipun terkadang politik hukum justru menjauhkan tata hukum dari realitas sosialnya, yaitu dalam

\footnotetext{
${ }^{8}$ Abdul Hakim Garuda Nusantara, Politik Hukum Indonesia, Yayasan Lembaga Bantuan Hukum Indonesia, Jakarta, 1988, hlm. 20. 11.

${ }_{9}^{9}$ Bernard L. Tanya, Politik Hukum: Agenda Kepentingan Bersama, Genta Publishing, Yogyakarta, 2011, hlm.

${ }^{10}$ E. Utrecht, Pengantar Dalam Hukum Indonesia, Pradnya Paramitha, Jakarta, 1961, hlm. 53.
} 
hal politik hukum menjadi alat dan tangan suatu ruling class yang hendak berkuasa tanpa mempeerhatikan fakta sosial.

Sementara Mochtar Kusumaatmadja ${ }^{11}$ memandang politik hukum (rechts politiek) adalah kebijakan hukum dan perundang-undangan dalam rangka pembaharuan hukum. Dalam sistem hukum Indonesia dimana undang-undang merupakan cara pengaturan hukum yang utama. Proses pembentukan undangundang harus dapat mengakomodir seluruh persoalan yang berkaitan dengan bidang atau masalah yang hendak diatur. Efektifitas produk perundang-undangan dalam penerapannya memerlukan perhatian lembaga dan prosedur yang diperlukan dalam pelaksanaanya. Mochtar menambahkan, terdapat kusulitan dalam proses pembentukan perundang-undangan, yaitu, pertama, menentukan prioritas kebutuhan masyarakat secara rasional dan pasti. Kedua, membuat hukum yang sesuai dengan kebutuhan dan kesadaran masyarakat. ${ }^{12}$

Satjipto Rahardjo ${ }^{13}$ mengemukakan bahwa tujuan dari politik hukum adalah proses pemilihan tujuan diantara berbagai tujuan yang mungkin. Dengan kata lain, politik hukum adalah aktivitas memilih suatu tujuan sosial tertentu. Dalam pembangunan hukum senantiasa dihadapkan pada persoalan yang mengharuskan untuk menentukan pilihan mengenai tujuan maupun cara-cara yang hendak dipergunakan untuk mencapai tujuan tersebut. Sehingga untuk menenentukan hal tersebut, perlu memperhatikan beberapa hal: ${ }^{14}$

a. Tujuan yang hendak dicapai dengan sistem hukum yang ada. Tujuan ini bisa berupa satu tujuan bsar yang tunggal, bisa juga terbagi-bagi ke dalam tujuan-tujuan yang lebih spesifik, dan mungkin masih dibagi lagi ke dalam tujuan-tujuan yang lebih kecil.

b. Cara yang paling tepat dan baik untuk bisa mencapai tujuan. Termasuk di dalamnya persoalan pemilihan antara hukum tertulis atau hukum yang tidak tertulis, antara sentralistik dan desentralistik.

c. Waktu untuk mengubah hukum serta cara-cara perubahan yang sebaiknya dilakukan.

d. Perumusan suatu pola yang mapan yang dapat memutuskan dalam proses pemilihan tujuan serta cara-cara untuk mencapai tujuan tersebut. Termasuk hlm. 8-9.

${ }^{11}$ Mochtar Kusumaatmadja, Hukum, Masyarakat dan Pembinaan Hukum Nasional, Bina Cipta, Bandung, 1986,

12 Ibid., hlm. 14.

${ }^{13}$ Satjipto Rahardjo, Ilmu Hukum, Cetakan Keenam, Citra Aditya Bakti, Bandung, 2006, hlm. 358-359.

${ }^{14}$ Ibid 
proses pembaharuan hukum secara efisien, baik perubahan secara keseluruhan, maupun hanya perubahan sebagian.

Kewenangan absolut lingkungan peradilan agama di bidang ekonomi syariah dalam ketentuan Pasal 49 Undang-Undang Nomor 3 Tahun 2006 tentang Perubahan atas Undang-Undang Nomor 7 Tahun 1989 tentang Peradilan Agama dan penjelasannya masih dinyatakan secara umum. Sedangkan mengenai sampai dimana batas ruang lingkup dan jangkauan kewenangan peradilan agama mengadili bidang ekonomi syariah, tidak ditegaskan secara eksplisit dalam undang-undang tersebut. ${ }^{15}$ Untuk itu, perlu perangkat peraturan lain yang dapat menopang kewenangan absolut peradilan agama di bidang penyelesaian sengketa ekonomi syariah

Lahirnya Undang-Undang Nomor 21 Tahun 2008 tentang Perbankan Syariah, memberikan harapan sebagai payung hukum dalam praktik bisnis bidang ekonomi syariah, dan diharapkan menguatkan eksistensi praktik perbankan syariah di Indonesia secara baik dan berkeadilan. Undang-undang tersebut juga mengatur tentang penyelesaian sengketa ekonomi syariah sebagai antisipasi terhadap persengketaan ekonomi syariah yang mungkin terjadi baik di masyarakat, LKS baik bank maupun nonbank. Hal ini dimaksudkan untuk menjamin keamanan dan kenyamanan berbagai pihak dalam melakukan transaksi. Terhadap cara penyelesaian sengketa perdata tersebut, khususnya sengketa bisnis dapat dilakukan melalui proses litigasi dan non litigasi. Jalur litigasi adalah proses penyelesaian melalui pengadilan, baik Pengadilan Agama (untuk sengketa ekonomi syariah) maupun Pengadilan Umum. Sementara jalur non litigasi adalah alternatif penyelesaian sengketa (Alternatief Dispute Resolution) melalui suatu badan arbritase. Pemilihan jalur-jalur penyelesaian tersebut ditentukan dalam klausul perjanjian sesuai dengan kesepakatan para pihak dalam berkontrak.

Penyelesaian jalur non litigasi biasanya dilakukan dengan cara musyawarah mufakat, mediasi serta melalui Badan Arbritase Syariah. Penyelesaian sengketa melalui jalur non ligitasi dipilih karena dianggap lebih mudah dan cepat. Sifat

${ }^{15}$ Cik Basir, Penyelesaian Sengketa Perbankan Syariah di Pengadilan Agama dan Mabkamah Syar'iyah, Prenada Media Group, Jakarta, 2009, hlm. 100. 
putusan arbitrase yang bersifat final dan binding merupakan salah satu alasan utama mengapa para pelaku bisnis memilih badan arbitrase dalam penyelesaian sengketa, karena dengan tidak terbukanya peluang banding dan kasasi maka kepastian hukum telah nampak jelas dalam putusan. Pelaksanaan putusan arbitrase oleh para pihak harus dipandang sebagai konsekuensi dipilihnya arbitrase untuk menyelesaikan sengketanya. Para pihaklah yang memilih hakimnya sendiri bahkan terhadap pilihan hukumnya, maka pelaksanaan dari putusan arbitrase pun secara sadar merupakan kebutuhan dari para pihak itu sendiri. Karena iktikad baik para pihak untuk melaksanakan isi putusan arbitrase merupakan faktor utama dalam penyelesaian sengketa bisnisnya.

Arbitrase sebagai lembaga penyelesaian sengketa, dapat memberikan keputusan yang sifatnya final dan mengikat. Idealnya, dengan putusan arbitrase tersebut maka para pihak yang bersengketa tidak lagi membawa permasalahan ke pengadilan, baik dalam hal permohonan eksekusi ataupun upaya membatalkan putusan arbitrase, ${ }^{16}$ meskipun kemungkinan itu bisa saja terjadi dan memang dimungkinkan oleh hukum. Dengan kata lain, salah satu pihak dapat mengajukan permohonan eksekusi kepada pengadilan terhadap putusan arbitrase yang tidak diindahkan oleh pihak lain, serta dapat melakukan permohonan pembatalan putusan arbitrase yang diduga mengandung kecacatan dalam pengambilan keputusannya.

Undang-Undang Nomor 48 Tahun 2009 tentang Kekuasaan Kehakiman, Pasal 59 dan penjelasannya justru mengatur mengenai ketentuan penyelesaian sengketa ekonomi syariah yang dianggap telah mereduksi kewenangan absolut peradilan agama. Hal ini bertentangan dengan penyelesaian sengketa ekonomi syariah sebagaimana ditetapkan dalam Undang-Undang Nomor 3 tahun 2006, yang dinyatakan bahwa:

Pasal 59 ayat (3):

"Dalam hal para pihak tidak melaksanakan putusan arbitrase secara sukarela, putusan dilaksanakan berdasarkan perintah ketua Pengadilan Negeri atas permohonan salah satu pihak yang bersengketa."17

${ }^{16}$ Edi Hudiata, Penyelesaian Sengketa Perbankan Syariah Pasca Putusan MK Nomor 93/PUU-X/2012: Litigasi dan Non Litigasi, UII Press, Yogyakarta, 2015, hlm. 107.

17 Pasal 59, ayat (3), Undang-Undang Nomor 48 Tahun 2009 tentang Kekuasaan Kehakiman. 
Penjelasan Pasal 59 ayat (1):

"Yang dimaksud "arbitrase" dalam ketentuan ini termasuk juga arbitrase syariah."18

Ketentuan Pasal 59 beserta penjelasannya di atas menunjukkan bahwa telah terjadi reduksi terhadap kompetensi peradilan agama dalam bidang penyelesaian sengketa ekonomi syariah, termasuk perbankan syariah, sebagaimana yang diamanahkan dalam Undang-Undang Nomor 3 Tahun 2006. Meskipun hal tersebut dimaksudkan untuk memudahkan penanganan perkara ekonomi syariah, namun secara yuridis ketentuan Pasal 59 Undang-Undang Nomor 48 Tahun 2009 beserta penjelasannya bertentangan dengan kekuasaan absolut peradilan agama dalam menangani perkara ekonomi syariah.

Dimasukkannya Pengadilan Negeri/Umum dan lembaga ekstra judicial (Badan Arbitrase Syariah Nasional) dalam penjelasan Pasal 55 ayat (2), maka penyelesaian sengketa perbankan syariah secara opsional memiliki tiga lembaga, yakni peradilan agama, peradilan negeri/umum, dan Badan Arbitrase Syariah Nasional (Basyarnas). Padahal kewenangan badan peradilan dalam memeriksa perkara tertentu secara mutlak tidak dapat diperiksa oleh badan peradilan lain, baik dalam lingkungan peradilan yang sama maupun dalam lingkungan peradilan yang berbeda. ${ }^{19}$

Pasal Pasal 59 Undang-Undang Nomor 48 Tahun 2009 yang memberikan kompetensi eksekusi dan pembatalan putusan arbitrase syariah melalui pengadilan negeri, jika diteliti secara mendalam, setidaknya terdapat dua kekeliruan mendasar. Pertama, secara kompetensi dan kedua, secara historis. Secara kompetensi, pemberian kewenangan eksekusi dan pembatalan putusan arbitrase syariah bukan merupakan kewenangan atau kompetensi dari pengadilan umum, mengingat prinsip-prinsip syariah atau agama Islam menjadi sumber hukum materiil dalam pelaksanaan sistem peradilan agama. Secara historis, pemberian kewenangan eksekusi dan pembatalan putusan arbitrase syariah ahistoris dengan kewenangan absolut Pengadilan Agama telah dituangkan dalam Pasal 49 Undang-

${ }^{18}$ Ibid., Penjelasan Pasal 59, ayat (1).

${ }^{19}$ Retnowulan Sutantio, Hukum Acara Perdata dalam Teori dan Praktik, Mandar Maju, Bandung, 1997, hlm. 8. Lihat pula; Sudikno Mertokusumo, Hukum Acara Perdata Indonesia, Liberty, Yogyakarta, 1985, hlm. 59. 
Undang Nomor 3 Tahun 2006 tentang Peradilan Agama, yang secara tegas memberikan kewenangan kepada peradilan agama untuk menerima, memeriksa dan menyelesaikan sengketa ekonomi syariah. Sudah seharusnya termasuk di dalamnya adalah sengketa yang diputus melalui lembaga arbitrase syariah. Undang-Undang Nomor 3 Tahun 2006 tentang Peradilan Agama ini kemudian disempurnakan dengan Undang-Undang Nomor 50 Tahun 2009 tentang Perubahan Kedua atas Undang-Undang Noomor 7 Tahun 1989 tentang Peradilan Agama, dan ketentuan dalam Pasal 49 ini tetap dipertahankan.

Berpegang pada deskripsi ini, maka secara horizontal Pasal 59 UndangUndang Nomor 48 Tahun 2009 yang memberikan kewenangan eksekusi dan pembatalan putusan arbtrase syariah kepada pengadilan umum, tidak sinkron dan tidak harmonis bahkan bertentangan dengan norma peraturan Pasal 49 UndangUndang Nomor 3 Tahun 2006 jo. Undang-Undang Nomor 50 Tahun 2009 tentang Peradilan Agama. Secara adrministratif, tidak boleh kewenangan absolut suatu lembaga peradilan dimiliki oleh lembaga peradilan lainnya.

Politik hukum Mahkamah Agung sebagai lembaga yang mempunyai kewenangan penyelesaian sengketa antar lembaga peradilan seharusnya mengambil langkah-langkah konkrit terkait aturan pelaksanaan dari ketentuan Undang-Undang. ${ }^{20}$ Secara internal, Mahkamah Agung menyelesesaikan dualisme kewenangan tersebut melalui politik hukum, dengan menerbitkan Peraturan Mahkamah Agung Nomor 14 Tahun 2016 tentang Tata Cara Penyelesaian Perkara Ekonomi Syariah. Dalam Pasal 13 ayat (2) menegaskan bahwa pelaksanaan putusan arbitrase syariah dan pembatalannya, dilakukan oleh pengadilan dalam lingkungan peradilan agama, namun secara yuridis normatif hal tersebut masih menyisakan pertentangan norma antarundang-undang. Idealnya, kewenangan yang menjadi kompetensi absolut suatu lembaga peradilan dituangkan di dalam dalam suatu undang-undang yang baku, bukan dengan cara tambal sulam melalui peraturan lainnya yang secara hierarkis lebih rendah dari undang-undang.

${ }^{20}$ Erie Hariyanto, "Penyelesaian Sengketa Ekonomi Syariah di Indonesia," Jurnal Iqtishadia Volume 1, Nomor 1, Juni 2014, hlm. 53. 
Pengaturan Kewenangan Pelaksanaan Eksekusi dan Pembatalan Putusan Arbitrase Syariah dalam Penyelesaian Sengketa Ekonomi Syariah di Indonesia

Adanya dualisme kewenangan dalam melaksanakan eksekusi dan pembatalan putusan arbitrase syariah sudah pasti berakibat terhadap ketidakpastian hukum, yang mengakibatkan kebingungan bagi para pelaku bisnis syariah dalam mencari keadilan. Terjadinya tarik ulur dualisme kewenangan dalam pelaksanaan eksekusi dan pembatalan putusan arbitrase syariah antara Pengadilan Negeri dan Pengadilan Agama, tidak terlepas dari faktor historis, faktor politis dan faktor yuridis. Ketiga faktor tersebut secara langsung mempengaruhi lahirnya produk perundang-undangan yang mengatur tentang hukum Islam di Indonesia. Untuk membenahi persoalan tarik ulur dualisme kewenangan tersebut, maka beberapa hal berikut perlu untuk dilakukan, guna merekonstruksi kewenangan eksekusi dan pembatalan putusan arbitrase syariah agar lebih menjamin kepastian hukum bagi masyarakat. Maka untuk menjamin kepastian hukum dalam hal tersebut perlu dilakukan pemahaman yang utuh dan komprehensif terhadap peraturan perundang-undangan yang melingkupinya.

Undang-Undang Nomor 21 Tahun 2008 tentang Perbankan Syariah, dalam Pasal 55 juga telah menegaskan bahwa kewenangan untuk menangani perkara ekonomi syariah adalah merupakan wilayah kewenangan dari peradilan agama;

(1)Penyelesaian sengketa Perbankan Syariah dilakukan oleh pengadilan dalam lingkungan Peradilan Agama.

(2)Dalam hal para pihak telah memperjanjikan penyelesaian sengketa selain sebagaimana dimaksud pada ayat (1), penyelesaian sengketa dilakukan sesuai dengan isi Akad.

(3)Penyelesaian sengketa sebagaimana dimaksud pada ayat (2) tidak boleh bertentangan dengan Prinsip Syariah. ${ }^{21}$

Pasal 55 ayat (3) di atas ditegaskan bahwa penyelesaian sengketa ekonomi syariah tidak boleh bertentangan dengan prinsip-prinsip syariah. Hal ini tidak mungkin terpenuhi jika pemeriksaan dan penanganan perkaranya diberikan kepada Pengadilan Negeri/Umum, karena hukum materiil dari Pengadilan Umum tidak berdasarkan pada prinsip-prinsip syariah. Pengadilan Agama-lah yang menggunakan hukum Islam/syariah sebagai sumber hukum materiilnya. Selain

21 Pasal 55, Undang-Undang Nomor 21 Tahun 2008 tetang Perbankan Syariah. 
hal tersebut, tidak mungkin satu kewenangan absolut diberikan kepada dua lembaga peradilan yang berbeda.

Penyelesaian sengketa ekonomi syariah tetap menjadi kompetensi absolut peradilan agama dan tidak dapat diperiksa oleh badan pengadilan lainnya. Walaupun para pihak diberikan kebebasan untuk menentukan mekanisme penyelesaian sengketa, namun tetap proses penyelesaiannya berdasarkan prinsip syariah. Hal ini didasarkan bahwa hubungan hukum yang terjadi antara subyek hukum berdasarkan prinsip syariah akan melahirkan akibat hukum dan dalam proses penyelesainnya berdasarkan pula pada prinsip syariah. Sementara pengadilan yang mampu menerapkan prinsip syariah hanyalah Pengadilan Agama. ${ }^{22}$ Oleh karena itu, sudah selayaknya untuk dilakukan pembenahan dan perbaikan terhadap Pasal 59 Undang-Undang Nomor 48 Tahun 2009 dan UndangUndang Nomor 30 Tahun 1999, yang jika dilihat dari segi usianya sudah cukup tua, sehingga kurang mengakomodir perkembangan sistem penyelenggaraan bisnis dan ekonomi di masyarakat yang bergerak sangat dinamis.

Dasar hukum arbitrase syariah masih mengacu pada Undang-Undang Nomor 30 Tahun 1999 yang menyebutkan kewenangan untuk pelaksanaan atau eksekusi putusan badan arbitrase harus ke Pengadilan Negeri. Akan tetapi khusus untuk putusan Badan Arbitrase Syariah Nasional diharapkan kewenangan tersebut beralih ke Pengadilan Agama sesuai dengan hukum yang di berlakukan oleh Badan Arbitrase Syariah Nasional yaitu hukum Islam. ${ }^{23}$

Revisi undang-undang arbitrase dan penyelesaian sengketa, diharapkan bisa mengakomodir arbitrase syariah sebagai lembaga pilihan dalam menyelesaikan sengketa ekonomi syariah yang kian banyak diminati. Melalui undang-undang yang baik diharapkan mampu menciptakan ketertiban dalam praktik-praktik perekonomian di Indonesia, dengan menjamin keadilan secara yuridis-normatif yang komprehensif.

22 Tuti Haryanti, "Kewenangan Peradilan Agama dalam Penyelesaian Sengketa Ekonomi Syariah,” Jurnal Tabkim Volume IX, Nomor 1, Juni 2013, hlm. 83.

${ }^{23}$ Ummi Umza, "Pelaksanaan atau Eksekusi Putusan Badan Arbitrase Syariah Nasional (BASYARNAS) Sebagai Kewenangan Pengadilan Agama," Jurnal Hukum dan Pembangunan Tahun ke-44, Nomor 3, September 2014, hlm. 402. 
Menurut kacamata Konstitusi, Pasal 59 ayat (3) dan Penjelasan Pasal 59 ayat (1) Undang-Undang Nomor 48 Tahun 2009 tentang Kekuasaan Kehakiman juga bertentangan dengan Pasal 29 ayat (2) Undang-Undang Dasar 1945, dimana "Negara menjamin kemerdekaan tiap penduduk pemeluk agamanya untuk melaksanakan syariatnya". Melaksanakan praktik ekonomi syariah dan menyelesaikan sengketanya melalui peradilan agama adalah merupakan bentuk implementasi dari Pasal 29 ayat (2) itu sendiri, mengingat hanya Pengadilan Agama yang menjadikan hukum Islam/syariah sebagai sumber hukum materiil dalam memeriksa dan memutus perkara. Maka negara mempunyai kewajiban melindungi hak-hak hukum bagi setiap warga negaranya.

Selain secara konstitusional bertentangan dengan Pasal 29 ayat (2), Pasal 59 ayat (3) dan Penjelasan Pasal 59 ayat (1) Undang-Undang Nomor 48 Tahun 2009 tentang Kekuasaan Kehakiman juga bertentangan dengan Pasal 28D UndangUndang Dasar 1945, bahwa "Setiap orang berhak atas pengakuan, jaminan, perlindungan, dan kepastian hukum yang adil serta perlakuan yang sama di hadapan hukum". Kepastian hukum dalam konteks kewenangan eksekusi dan pembatalan putusan arbitrase dalam penelitian ini adalah tidak adanya dualisme kewenangan absolut terhadap hal tersebut yang dimiliki oleh dua lembaga peradilan yang berbeda, yaitu Pengadilan Negeri dan Pengadilan Agama. Wilayah ini merupakan kewenangan Mahkamah Konstitusi, yakni menguji materi Undang-Undang terhadap Undang-Undang Dasar.

Tantangan ekonomi syariah ke depan lebih besar, sehingga semua langkah konstruktif dan antisipatif harus digagas dan dilakukan sejak dini. Agar implementasi dari pelaksanaan penyelesaian sengketa relevan terhadap prinsipprinsip syariah dengan lembaga peradilan, maka diharapkan agar pemerintah melakukan revisi terkait undang-undang. ${ }^{24}$ Dalam politik hukum Indonesia ke depan, penting pula untuk memperhatikan harmonisasi dalam penyusunan peraturan perundang-undangan. Karena meskipun mengatur bidang hukum yang berbeda, namun pada hakikatnya satu sama lain saling berkaitan dan tidak bisa

${ }^{24}$ Andi Tenri Soraya, M. Arifin Hamid, dan Juajir Sumardi, "BASYARNAS Sebagai Lembaga Alternatif Penyelesaian Sengketa Bisnis Syariah,” Jurnal Analisis Volume 3, Nomor 2, Desember 2014, hlm. 179. 
berdiri sendiri. Untuk itu dalam pembangunan sistem hukum Indonesia ke depan, dibutuhkan perencanaan yang matang untuk melahirkan produk hukum yang bulat, utuh, dan komprehensif. Apabila proses harmonisasi horizontal ini tidak terlaksana dengan baik, maka akan melahirkan peraturan yang tumpang tindih dan saling bertentangan antar sektor hukum. Hal ini akan mengakibatkan ketidakpatian hukum dan ambiguitas dalam penerapan peraturan perundang-undangan, yang berakibat terhadap gagalnya pencapaian tujuan sistem hukum suatu negara.

Hukum diharapkan hadir di tengah-tengah masyarakat serta dijalankan tidak sekadar menurut kata-kata hitam-putih dari peraturan (according to the letter), melainkan menurut semangat dan makna lebih dalam (to the very meaning) dari undang-undang atau hukum. Hukum tidak hanya dijalankan dengan kecerdasan intelektual saja, melainkan juga dengan kecerdasan spiritual. Menjalankan hukum harus dengan determinasi, empati, dedikasi, komitmen terhadap penderitaan bangsa untuk berani mencari jalan lain guna kebenaran, keadilan dan kepastian hukum para pencari keadilan.

\section{Penutup}

Berdasarkan uraian serta pembahasan di atas, maka dapat ditarik kesimpulan sesuai dengan masalah pokok dalam penelitian ini: Pertama, konstruksi hukum terkait eksekusi dan pembatalan putusan arbitrase syariah di Indonesia terdapat pertentangan dalam pengaturan kewenangan pelaksanaannya. Pertentangan tersebut berupa dualisme aturan yang memberikan kewenangan pelaksanaan eksekusi dan putusan arbitrase syariah melalui peradilan umum dan peradilan agama. Dualisme ini mempunyai kekeliruan mendasar, baik secara kompetensi maupun secara historis. Mengingat prinsip-prinsip syariah yang digunakan dalam arbitrase syariah seharusnya menjadi kompetensi peradilan agama serta bertentangan dengan UU Peradilan Agama yang memberikan kewenangan atas sengketa ekonomi syariah ke peradilan agama. Dalam menghadapi dualisme tersebut, secara politik hukum, Mahkamah Agung sebagai lembaga yang mempunyai kewenangan penyelesaian sengketa antar lembaga peradilan seharusnya mengambil langkah-langkah konkrit dengan menerbitkan PERMA Nomor 14 Tahun 2016 yang menegaskan bahwa pelaksanaan eksekusi dan 
pembatalan putusan arbitrase syariah merupakan kewenangan dari Peradilan Agama. Meski demikian, dalam tataran undang-undang, masih terjadi pertentangan norma.

Kedua, perlu pembenahan hukum dalam pengaturan kewenangan pelaksanaan eksekusi dan pembatalan putusan arbitrase syariah guna menjamin kepastian hukum agar tidak saling bertentangan antara satu dengan lainnya. Ke depan, eksekusi dan pembatalan arbitrase syariah seharusnya ditempatkan di Pengadilan Agama. Arbitrase syariah merupakan bagian dari upaya penyelesaian sengketa ekonomi syariah, yang menggunakan prinsip-prinsip syariah. Dalam hal ini, Pengadilan Agamalah yang berwenang untuk mengadili sengketa tersebut karena menggunakan hukum Islam sebagai sumber hukum materiilnya. Pembenahan tersebut dapat dilakukan melalui perencanaan yang matang dalam pembangunan sistem hukum Indonesia di masa yang akan datang, baik dalam jangka waktu yang pendek, menengah ataupun jangka panjang, atau dalam istilah lain disebut dengan politik hukum nasional.

Pemberian kewenangan pelaksanaan eksekusi dan pembatalan putusan arbitrase syariah, terdapat beberapa hal yang perlu dibenahi, yakni melakukan sinkronisasi undang-undang melalui revisi undang-undang oleh Pemerintah bersama Dewan Perwakilan Rakyat. Undang-Undang Nomor 30 Tahun 1999 tentang Arbitrase dan Alternatif Penyelesaian Sengketa yang menjadi landasan yuridis penyelesaian sengketa di luar pengadilan dianggap tidak lagi sesuai dengan konteks perkembangan arbitrase di Indonesia. Perlu dilakukan revisi terhadap undang-undang tersebut agar bisa mengakomodir perkembangan arbitrase, khususnya lembaga arbitrase syariah yang menggunakan hukum Islam. Selain itu, perlu penguatan kelembagaan. Dengan bertambahnya kewenangan yang diberikan kepada pengadilan agama, maka seyogyanya secara kelembagaan perlu membekali pengutan sesuai dengan kompetensinya.

\section{Daftar Pustaka}

\section{Buku}

Ahmad, Amrullah, dan kawan-kawan, Dimensi Hukum Islam dalam Sistem Hukum Nasional; Mengenang 65 Tahun Prof. Dr. Bustanul Arifin, SH, Gema Insani Press, Jakarta, 1996. 
Basir, Cik, Penyelesaian Sengketa Perbankan Syariah di Pengadilan Agama dan Mahkamah Syar'iyah, Prenada Media Group, Jakarta, 2009.

Djamil, Fathurrahman, Hukum Ekonomi Islam; Sejarah, Teori dan Konsep, Sinar Grafika, Jakarta, 2013.

Hartono, Sunaryati, Politik Hukum Menuju Satu Sistem Hukum Nasional, Alumni, Bandung, 1991.

Hudiata, Edi, Penyelesaian Sengketa Perbankan Syariah Pasca Putusan MK Nomor 93/PUU-X/2012 : Litigasi dan Non Litigasi, UII Press, Yogyakarta, 2015.

Kusumaatmadja, Mochtar, Hukum, Masyarakat dan Pembinaan Hukum Nasional, Bina Cipta, Bandung, 1986.

Mahfud MD, Moh, Politik Hukum di Indonesia, Cetakan Keenam, Raja Grafindo Persada, Jakarta, 2014.

Manan, Abdul, Politik Hukum: Studi Perbandingan dalam Pratik Ketatanegaraan Islam dan Sistem Hukum Barat, Prenada Media Group, Jakarta, 2016.

Mertokusumo, Sudikno, Hukum Acara Perdata Indonesia, Liberty, Yogyakarta, 1985.

Nusantara, Abdul Hakim Garuda, Politik Hukum Indonesia, Yayasan Lembaga Bantuan Hukum Indonesia, Jakarta, 1988.

Rahardjo, Satjipto, Ilmu Hukum, Cetakan Keenam, Citra Aditya Bakti, Bandung, 2006.

Tanya, Bernard L., Politik Hukum: Agenda Kepentingan Bersama, Genta Publishing, Yogyakarta, 2011.

Utrecht, E., Pengantar Dalam Hukum Indonesia, Pradnya Paramitha, Jakarta, 1961.

\section{Jurnal}

Faisol, Muhammad, "Pasang Surut Undang-Undang Peradilan Agama: Problem Penyelesaian Sengketa Ekonomi Syariah," Jurnal al-Adalah Volume 16, Nomor 2, Nopember 2012.

Hariyanto, Erie, "Penyelesaian Sengketa Ekonomi Syariah di Indonesia," Jurnal Iqtishadia Volume 1, Nomor 1, Juni 2014.

Soraya, Andi Tenri, M. Arifin Hamid, dan Juajir Sumardi, “BASYARNAS Sebagai Lembaga Alternatif Penyelesaian Sengketa Bisnis Syariah," Jurnal Analisis Volume 3, Nomor 2 (Desember 2014).

Haryanti, Tuti, "Kewenangan Peradilan Agama dalam Penyelesaian Sengketa Ekonomi Syariah," Jurnal Tahkim Volume IX, Nomor 1, Juni 2013.

Soraya, Andi Tenri, M. Arifin Hamid, dan Juajir Sumardi, "BASYARNAS Sebagai Lembaga Alternatif Penyelesaian Sengketa Bisnis Syariah," Jurnal Analisis Volume 3, Nomor 2 Desember 2014.

Umza, Ummi, "Pelaksanaan atau Eksekusi Putusan Badan Arbitrase Syariah Nasional (BASYARNAS) Sebagai Kewenangan Pengadilan Agama," Jurnal Hukum dan Pembangunan Tahun ke-44 Nomor 3 September 2014. 


\section{Peraturan Perundang-undangan}

Undang-Undang Nomor 3 Tahun 2006 tentang Perubahan Undang-Undang Nomor 70 Tahun 1989 tentang Peradilan Agama, Lembaran Negara Nomor 22 Tahun 2006, Tambahan Lembaran Negara Nomor 4611.

Undang-Undang Nomor 21 Tahun 2008 tetang Perbankan Syariah, Lembaran Negara Nomor 94 Tahun 2008, Tambahan Lembaran Negara Nomor 4867.

Undang-Undang Nomor 48 Tahun 2009 tentang Kekuasaan Kehakiman, Lembaran Negara Nomor 157 Tahun 2009, Tambahan Lembaran Negara Nomor 5076. 